\title{
Diversity of Medicinal Plants among Different Tree Canopies
}

\author{
Muhammad Zubair 1,*, Akash Jamil 1미, Syed Bilal Hussain ${ }^{2}$, Ahsan Ul Haq ${ }^{3}$, Ahmad Hussain ${ }^{4}$, \\ Din Muhammad Zahid ${ }^{1}$, Abeer Hashem ${ }^{5}$, Abdulaziz A. Alqarawi ${ }^{6}$ and Elsayed Fathi Abd_Allah ${ }^{6}$ (D)
}

1 Department of Forestry and Range Management, FAS\&T, Bahauddin Zakariya University, Multan 60000, Pakistan; akashjamil2@live.com (A.J.); dmzahid@bzu.edu.pk (D.M.Z.)

2 Institute of Molecular Biology and Biotechnology, Bahauddin Zakariya University, Multan 60000, Pakistan; drsbhussain@gmail.com

3 Department of Forestry and Range Management, University of Agriculture, Faisalabad 38040, Pakistan; ahsanmalik411@hotmail.com

4 Department of Forestry and Wildlife Management, University of Haripur, Haripur 22620, Pakistan; ahmad.hussain@uoh.edu.pk

5 Botany and Microbiology Department, College of Science, King Saud University, P.O. Box. 2460, Riyadh 11451, Saudi Arabia; habeer@ksu.edu.sa

6 Plant Production Department, College of Food and Agricultural Sciences, King Saud University, P.O. Box 2460, Riyadh 11451, Saudi Arabia; alqarawi@ksu.edu.sa (A.A.A.); eabdallah@ksu.edu.sa (E.F.A.)

* Correspondence: zubair.fast@bzu.edu.pk

Citation: Zubair, M.; Jamil, A.; Hussain, S.B.; Ul Haq, A.; Hussain, A.; Zahid, D.M.; Hashem, A.; Alqarawi, A.A.; Abd_Allah, E.F. Diversity of Medicinal Plants among Different Tree Canopies. Sustainability 2021, 13, 2640. https://doi.org/10.3390/su 13052640

Academic Editor: Susana Santos

Received: 20 December 2020

Accepted: 12 February 2021

Published: 2 March 2021

Publisher's Note: MDPI stays neutral with regard to jurisdictional claims in published maps and institutional affiliations.

\begin{abstract}
The moist temperate forests in Northern Pakistan are home to a variety of flora and fauna that are pivotal in sustaining the livelihoods of the local communities. In these forests, distribution and richness of vegetation, especially that of medicinal plants, is rarely reported. In this study, we carried out a vegetation survey in District Balakot, located in Northeastern Pakistan, to characterize the diversity of medicinal plants under different canopies of coniferous forest. The experimental site was divided into three major categories (viz., closed canopy, open spaces, and partial tree cover). A sampling plot of $100 \mathrm{~m}^{2}$ was established on each site to measure species diversity, dominance, and evenness. To observe richness and abundance, the rarefaction and rank abundance curves were plotted. Results revealed that a total of 45 species representing 34 families were available in the study site. Medicinal plants were the most abundant ( $45 \%$ ) followed by edible plants (26\%). Tree canopy cover affected the overall growth of medicinal plants on the basis of abundance and richness. The site with partial canopy exhibited the highest diversity, dominance, and abundance compared to open spaces and closed canopy. These findings are instrumental in identifying the wealth of the medicinal floral diversity in the northeastern temperate forest of Balakot and the opportunity to sustain the livelihoods of local communities with the help of public/private partnership.
\end{abstract}

Keywords: biodiversity; biodiversity indices; non-wood forest products; medicinal plant inventory; forest canopies

\section{Introduction}

Pakistan harbors a sizable range of lesser Himalayas, as they cover part of the northern province of the country. The mountain range harbors various biodiversity hotspots, including dense forests and extensive grasslands. This ecosystem has a majority of important flora and fauna endemic to this region [1,2]. The local inhabitants are directly or indirectly dependent upon resources from these forests, particularly non-wood forest products (NWFPs) [3,4]. NWFPs in any forest biome are categorized into edible, medicinal, and constructional products [5]. These products have particular roles in the lives of the local communities. Most important among these NWFPs are the medicinal plants, as the local people in the Himalayas use about 500 of these plant species in their traditional health care practices [6-11]. Pakistan has about 6000 plant species, of which about 33\% are being used as NWFPs. Among these NWFPs, about 50\% are extensively used as medicinal 
plants [12-14]. The role of NWFPs in socioeconomics is well documented. Owing to the socioeconomic and environmental value of NWFPs in moist temperate forests of Pakistan, conservation of these resources is of vital importance [10-12].

Diversity of vegetation is known to have a direct effect on vegetation structure, ecosystem functions, and biogeochemical cycles of a specific ecosystem $[15,16]$. Measuring plant biodiversity in mountainous regions provides crucial knowledge regarding the suitability of the specific habitat, productivity of the ecosystem, and prediction of successional pathways [17-19].

Literature reveals that the Hindu Kush and Himalayan regions in Pakistan have approximately 4000 floral species, the majority of which are endemic $[20,21]$. These regions, due to frequent natural calamities and human interventions, are prone to habitat degradation and habitat loss that consequently leads to the extinction of crucial endemic species [22]. Recently, deforestation and natural disasters have triggered structural changes in the Himalayas' forests [23]. Recent earthquakes have jolted the Himalayan forests, causing havoc for the forest resources and the people dependent upon them [2,24]. Various studies have revealed that earthquakes in the Himalayan forests have caused swift deterioration in both the abundance and diversity of understory [25-27].

Forest canopies are known to be the engines and hotspots of plant diversity, biochemical processes, and interfaces between organisms and the atmosphere [28]. Canopy cover of the forest stand is implicated in maintaining the biodiversity and providing various ecosystem services $[29,30]$. Forest canopies support nearly $40 \%$ of world's existing species, among which about $10 \%$ are termed as canopy specialists [31]. Plant species directly or indirectly are dependent upon tree canopies for nutrients, sunlight, and reproduction aid $[32,33]$. Various authors have reported that the disturbance in the canopy has direct effects on the density and abundance of understory vegetation [34,35].

Medicinal plants have an integral representation in the understory vegetation of a forest $[9,36]$. Adnan and Holscher [20] compared the diversity and density of medicinal plants among the old growth forest and the degraded forest and showed that the density of medicinal plants was much higher in old growth forest as compared to the degraded forest. The amount of quantitative vegetation surveys in the Himalayas are quite limited and insufficient to visualize a clear picture of understory vegetation diversity [10,37]. It is important to document the diversity of vegetation, especially the status of medicinal plants in the region for policy development and sustainable management practices [10]. As a major proportion of the forest communities are dependent upon these resources for economics, edibles, constructional and medicinal purposes, and restoration of ecosystem services and biodiversity, it is necessary that these wild and precious resources be conserved $[2,20,24]$. Furthermore, there are very few investigations on the effects of different forest canopies on the diversity of medicinal plants [38-40]. The current study aims to depict the biodiversity of medicinal plants in the selected forest and displays the effect of canopies on the diversity and abundance of the medicinal plants. Even though numerous studies are available highlighting the significance and diversity of medicinal plants in this region, this study adds a new dimension of knowledge in terms of the role of various forest canopies influencing the diversity, distribution, and abundance of medicinal plants. The specific objectives of the research were firstly to find how much of NWFP biodiversity corresponds to medicinal plants and secondly to identify if the top story of the forest, i.e., the canopy of the trees, has a role in such diversity.

\section{Methodology}

\subsection{Description of the Study Site}

Naga Forest Reserve is located $30 \mathrm{~km}$ north of Balakot. It is situated at $34.6528^{\circ} \mathrm{N}$, $73.3586^{\circ} \mathrm{E}$ (Figure 1). This is a protected moist temperate forest lying in the Himalayan mountain range, covering an area of 6254 hectares (ha). The study area was selected after discussion with forest department officials due to its accessibility and suitability for the objectives of this study. The vegetation in the forest includes relics of evergreen forests, 
dominated by Cedrus deodara (Roxb. ex Lambert) G.Don, Pinus wallichiana A.B.Jacks, and Abies pindrow Royle. It also consists of patches of deciduous forests in which stands of Juglans regia L. prevail. The forest reserve experiences heavy rains throughout the summer. The rainfall becomes more frequent in the monsoon season, the average being $2500 \mathrm{~mm}$. The maximum and minimum temperature is $43.5^{\circ} \mathrm{C}$ and $-3{ }^{\circ} \mathrm{C}$ respectively. The winters are characterized by heavy snow that starts from the latter half of November and continues to the end of March. The summers are very short, only lasting for about 4 months from May to August. Short summer periods provide very limited time for the growth of trees and understory vegetation. The average altitude of the forest is $2416 \mathrm{~m}$. Owing to suitable weather and ease of access, we conducted this study in the summer season.

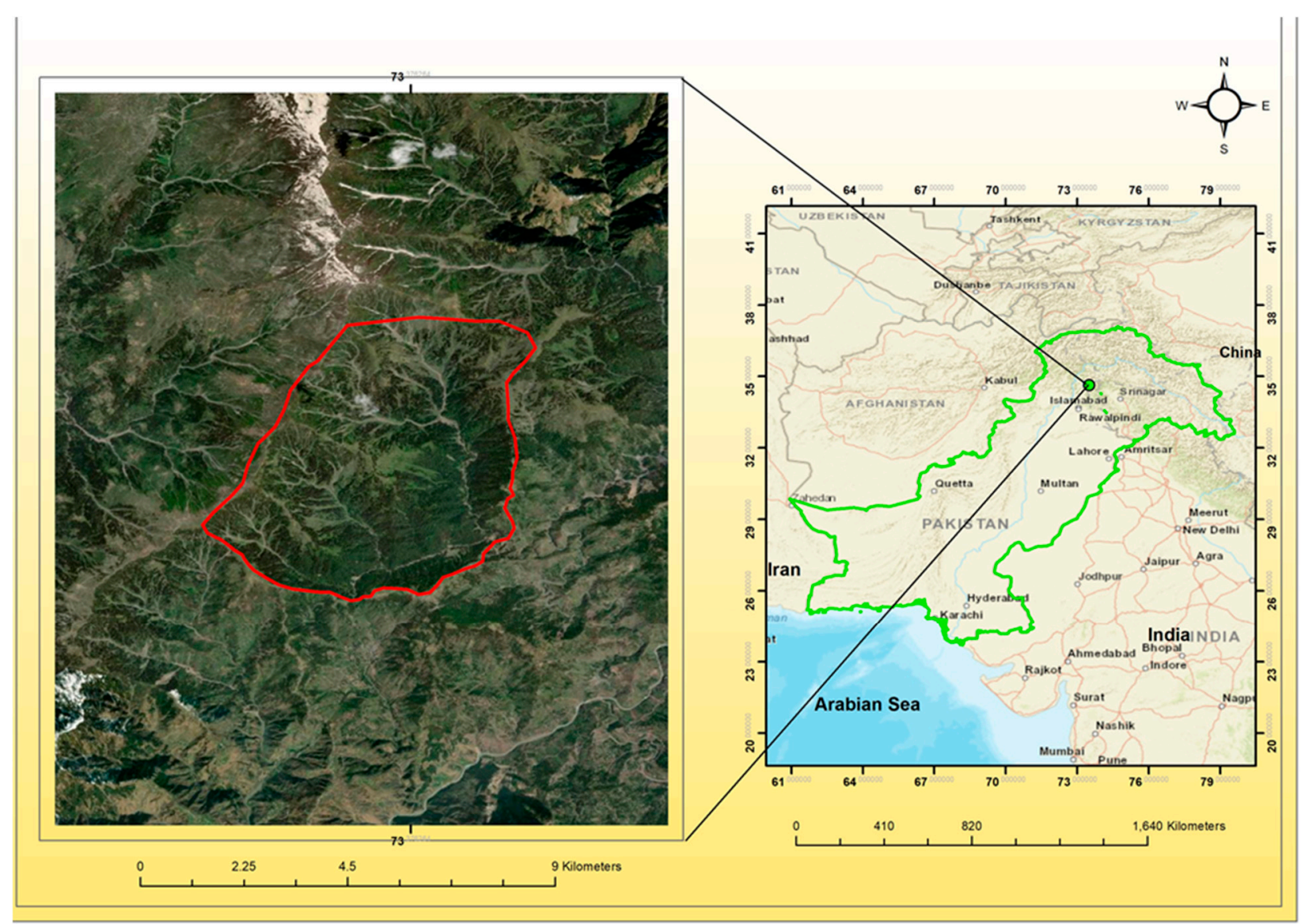

Figure 1. Study Site: Naga Forest Reserve, Balakot, KPK Punjab.

\subsection{Sampling Methods and Instruments}

The data were obtained using conventional techniques of vegetation inventory. In order to determine the biodiversity of the area, three nested sampling plots were established. The study sites were divided on the basis of canopy cover: closed canopy at the altitude of $2514 \mathrm{~m}$, open space (grass land) at the altitude of $2648 \mathrm{~m}$, and partial canopy at the altitude of $2450 \mathrm{~m}$. Several instruments were used to collect field data: a $1 \times 1 \mathrm{~m}$ quadrat, weight balance, GPS, measuring tape, clipper, pegs and field note book/range vegetation forms, map of the area, paper sacks, pencil, sharpeners, and erasers.

\subsection{Data Collection}

Each sampling plot was of $100 \mathrm{~m}^{2}$ in which about 10 quadrates of $1 \mathrm{~m}^{2}$ each were placed randomly at each site. A total of 30 quadrates were taken in between July and August 2018 from the selected sites (closed canopy, open space, and partial canopy) to reduce bias in the data. The vegetation inside the quadrate was taken out with the help of a 
clipper affixed at $25 \mathrm{~cm}$ starting from the base of the plant. The clipped samples were placed in paper bags and were freshly weighted using a portable weight balance then placed in paper bags. These bags were then taken in the laboratory. These samples were then transferred into an oven and dried at $70^{\circ} \mathrm{C}$ for $48 \mathrm{~h}$ until a constant weight was achieved. The samples were then weighed again for biomass determination of the vegetation. The rules for nomenclature as proposed by Peruzzi [41] were considered and vegetation data was quantitatively analyzed for frequency $(\mathrm{F})$ and density (D). Plant species nomenclature follows terminology laid out by the Global Biodiversity Information Facility (gbif.org) [42] and family names follow the Angiosperm Phylogeny Group III classification [43].

\subsection{Data Analyses}

A detailed biodiversity analysis was performed. Basic quantitative analysis involving F,D, and abundances of vegetation was calculated using Curtis and McIntosh [44], distribution of species abundance was assessed following Miller and Wiegert [45], and to determine how dominant a species is in a given site, the important value index (IV) was used [46]. In order to determine species richness, dominance, heterogeneity, and evenness, various indices such as Margalef's, Simpson's, Shannon's, and Buzas and Gibson's index were calculated respectively [47-50]. The similarities in plant species composition among the various sampling sites were calculated using the Sørensen Dice Index [51]. Furthermore, the rank abundance curve was plotted in order to visualize species richness and evenness. Rank abundance curve is useful as it incapacitates the inadequacies of biodiversity indices, which are unable to display the relative part different variables played in their calculation $[52,53]$. In order to display the efficacy of sampling, true species richness in a specific habitat and the comparison of species richness among various habitats on an equal effort basis rarefaction curves were plotted $[54,55]$.

\section{Results}

\subsection{Vegetation Description of the Study Site}

The study area exhibited a dense understory vegetation. The overall biodiversity of floral species in the area was considerable although the forest was partially open for the community in order to graze and collect plants. A total of 3200 plant individuals representing 45 species belonging to 34 families were identified from the understory vegetation of the study site. The plant species present mostly were indigenous in nature. About $70 \%$ of plants identified were herbs. The shrubs found in the site were $21 \%$ and only $9 \%$ of fern species were available in the study site. The forest surveyed showed that about $71 \%$ of plants found were being used for medicinal purposes by the local community. The data was taken from three different sites, viz., understory in a closed canopy site, vegetation from the open spaces, and sites partially covered with trees. It was noted that the observed species in partial and closed canopy sites were a little richer (23) as compared to open spaces (17) and closed canopy sites (16) (Tables 1-3).

\subsection{Family Distribution of the Study Site}

From the 34 plant families found, the most abundant and dense in the forest was Rosaceae. The family Fabaceae also existed as dominant, whereas the least dominant family was Urticaceae. The important value index (IV) showed that in a particular site the dominant species were not equally distributed. The highest IV value was of Geranium wallichianum D.Don ex Sweet, recorded at 0.84 , and the majority of species had values in the range of $0.02-0.13$. It was observed that in all 3 sites, only 3 species had values nearing the 0.8 range (Tables 1-3) namely G. wallichianum, Valeriana wallichii DC., and Chrysopogon gryllus (L.) Trin. 


\subsection{Medicinal Plant Cover and Abundance between the Various Forest Canopies}

From the results of the comparison of the different forest canopies, we observed that the partial canopy had the maximum number of medicinal plants $(65 \%)$, followed by the closed canopy $(56 \%)$, and the open spaces $(41 \%)$.

\subsection{Closed Canopy}

The $\mathrm{F}$ and $\mathrm{D}$ values when calculated among the categorized sampling sites gave different results. During the sampling in the closed canopy site, about $56 \%$ of plant species identified were classified as extremely important medicinal plants, in which the most dominant one was $V$. wallichii $(\mathrm{F}=100 \% ; \mathrm{D}=173)$. Another medicinal plant that was significantly present in the site was Perilla frutescens Britton. $(\mathrm{F}=70 \% ; \mathrm{D}=113)$. G. wallichianum $(\mathrm{F}=60 \% ; \mathrm{D}=56)$, an endangered and endemic medicinal plant of the Himalayas, was also present in the study site [37]. Rare medicinal plants were also present, the most treasured of which was Podophyllum hexandrum Royle $(\mathrm{F}=10 \% ; \mathrm{D}=1)$. There were quite a few edible plants $(25 \%)$ also representing this site, the most prominent being Potentilla indica (Andrews) T. Wolf having the maximum F and D ( F $=100 \% ; \mathrm{D}=320)$. The others, such as Dryopteris filix-mas (L.) Schott $(\mathrm{F}=20 \% \mathrm{D}=18)$ and Viburnum grandiflorum Wall. $(\mathrm{F}=10 \% \mathrm{D}=2)$ were not quite as abundant but still were present in the site.

Table 1. Species Importance Index Values for the closed canopy plot in Naga forest (Rf: relative frequency, RD: relative density, C.P: Cover Percent, and IVI: Species Importance Value).

\begin{tabular}{|c|c|c|c|c|c|c|}
\hline Species & Classification & R.F & R.D & C.P & R.C & I.V \\
\hline Geranium wallichianum D. Don ex Sweet & Medicinal & 0.11 & 0.06 & 0.07 & 0.03 & 0.84 \\
\hline Valeriana wallichii DC. & Medicinal & 0.19 & 0.21 & 0.1 & 0.41 & 0.82 \\
\hline Potentilla indica (Andrews) T. Wolf & Fruit & 0.19 & 0.39 & 0.3 & 0.20 & 0.79 \\
\hline Perilla frutescens Britton. & Medicinal & 0.13 & 0.13 & 0.5 & 0.30 & 0.58 \\
\hline Dryopteris filix-mas (L.) Schott. & Vegetable & 0.03 & 0.02 & 0.2 & 0.1 & 0.17 \\
\hline Chrysopogon montanus Trin. & Animal forage & 0.01 & 0.02 & 0.18 & 0.10 & 0.14 \\
\hline Dryopteris austriaca Schinz \& Thell. & Vegetable & 0.05 & 0.04 & 0.04 & 0.02 & 0.13 \\
\hline Adiantum stenochlamys Baker & Medicinal & 0.05 & 0.03 & 0.02 & 0.01 & 0.11 \\
\hline Geranium nepalense Sweet & Medicinal & 0.03 & 0.01 & 0.03 & 0.02 & 0.07 \\
\hline Chrysopogon gryllus (L.) Trin. & Animal forage & 0.01 & 0.004 & 0.07 & 0.03 & 0.06 \\
\hline Viburnum grandiflorum Wall. & Fruit & 0.01 & 0.01 & 0.04 & 0.02 & 0.05 \\
\hline Gentiana decumbens L.f. & Medicinal & 0.01 & 0.003 & 0.04 & 0.02 & 0.04 \\
\hline Lavatera cachemiriana Cambess. & Medicinal & 0.01 & 0.001 & 0.003 & 0.02 & 0.04 \\
\hline Sonchus asper Hill & Animal forage & 0.01 & 0.01 & 0.003 & 0.001 & 0.03 \\
\hline Arisaema triphyllum (L.) Schott & Medicinal & 0.01 & 0.009 & 0.009 & 0.004 & 0.03 \\
\hline Podophyllum hexandrum Royle & Medicinal & 0.01 & 0.001 & 0.009 & 0.004 & 0.02 \\
\hline
\end{tabular}

\subsection{Open Spaces}

The $\mathrm{F}$ and $\mathrm{D}$ of the vegetation in the open spaces had little to no difference when compared to the closed canopy site. The only difference in the open spaces site was the representation of grasses and forage $(47 \%)$ in the majority that were utilized by the grazing community. The most abundant of them were $C$. gryllus $(\mathrm{F}=70 \%$; $\mathrm{D}=171)$, Trifolium repens L. $(\mathrm{F}=60 \%$; $\mathrm{D}=185)$, Gladiolus communis $\mathrm{L} .(\mathrm{F}=50 \%$; $\mathrm{D}=37)$, Primula denticulata Sm. $(\mathrm{F}=30 \% ; \mathrm{D}=11)$, Cyperus rotundus $\mathrm{L} .(\mathrm{F}=30 ; \mathrm{D}=46)$. The plants displaying medicinal characteristics were also represented in this site, having about $41 \%$ of the species, the most prominent and important being Hypericum perforatum $\mathrm{L}$. ( $\mathrm{F}=30 \% ; \mathrm{D}=41)$, Plantago ovata Forssk. ( $\mathrm{F}=20 \% \mathrm{D}=21)$, and Rumex nepalensis Spreng $(\mathrm{F}=20 \%$; $\mathrm{D}=13$ ) while the others were quite rare, having minimum frequencies and densities. The edible plants in this site were not very dominant and hence were sparsely scattered in the sampled site. Among the edibles, only $P$. indica $(F=40 \% \mathrm{D}=56)$ had considerable representation. 
Table 2. Species Importance Index Values for the open spaced plot in Naga forest (RF: relative frequency, RD: relative density, CP: Cover Percent, and IVI: Species Importance Value).

\begin{tabular}{ccccccc}
\hline Species & Classification & R.F & R.D & C.P & R.C & I.V \\
\hline Trifolium repens L. & Animal forage & 0.14 & 0.22 & 0.58 & 0.23 & 0.59 \\
Gladiolus communis L. & Aromatic & 0.11 & 0.04 & 0.21 & 0.08 & 0.25 \\
Chrysopogon gryllus (L.) Trin. & Animal forage & 0.16 & 0.20 & 0.63 & 0.25 & 0.24 \\
Cyperus rotundus L. & Animal forage & 0.07 & 0.05 & 0.18 & 0.07 & 0.19 \\
Potentilla indica (Andrews) T.Wolf & Fruit & 0.09 & 0.25 & 0.13 & 0.05 & 0.1 \\
Hypericum perforatum L. & Medicinal & 0.04 & 0.02 & 0.13 & 0.04 & 0.12 \\
Plantago ovata Forssk. & Medicinal & 0.04 & 0.02 & 0.13 & 0.05 & 0.12 \\
Rumex nepalensis Spreng. & Animal forage & 0.04 & 0.01 & 0.06 & 0.02 & 0.12 \\
Primula denticulate Sm. & Animal forage & 0.07 & 0.02 & 0.024 & 0.009 & 0.10 \\
Hyoscyamus niger L. & Medicinal & 0.02 & 0.05 & 0.04 & 0.01 & 0.10 \\
Skimmia laureola Siebold \& Zucc. Ex Walp. & Medicinal & 0.02 & 0.01 & 0.09 & 0.05 & 0.07 \\
Potentilla collettiana Aitch. \& Hemsl. & Fruit & 0.02 & 0.009 & 0.10 & 0.04 & 0.07 \\
Artemisia absinthium L. & Medicinal & 0.02 & 0.009 & 0.10 & 0.043 & 0.07 \\
Cynodon dactylon (L.) Pers. & Animal forage & 0.02 & 0.01 & 0.04 & 0.01 & 0.05 \\
Rubus niveus Thunb. & Fruit & 0.02 & 0.007 & 0.02 & 0.009 & 0.03 \\
Adiantum stenochlamys Baker & Medicinal & 0.02 & 0.006 & 0.01 & 0.004 & 0.03 \\
\hline
\end{tabular}

\subsection{Partial Canopy}

The third site, which had partial canopy cover, depicted a different trend when compared to the other two sites. This sampling area had the greatest number of species. Furthermore, this site had the maximum number of medicinal plants $(65 \%)$, the most dominant species being the Mentha spicata $\mathrm{L} .(\mathrm{F}=50 \%$; $\mathrm{D}=41)$, Polygonum amplexicule D. Don $(\mathrm{F}=30 \% ; \mathrm{D}=55)$ and Skimmia laureola Siebold \& Zucc. ex Walp. ( $\mathrm{F}=20 \%$; $\mathrm{D}=58$ ), while the other $52 \%$ of the medicinal plants in this site were quite rare and were not uniformly distributed. Among the rare species, the most important medicinal plants present were Paeonaia emodi Wall $(\mathrm{F}=10 \%$; $\mathrm{D}=35)$ Berberis lycium Royle $(\mathrm{F}=10 \% ; \mathrm{D}=1)$, Asparagus racemosus Willd ( $\mathrm{F}=10 \% ; \mathrm{D}=14)$, and $\mathrm{G}$. wallichianumi $(\mathrm{F}=10 \% ; \mathrm{D}=40)$. As compared to the closed canopy covered site, this area had quite a few varieties of grass species, the most dominant being the C. gryllus $(\mathrm{F}=100 \%$; $\mathrm{D}=150)$ and T. repens $\mathrm{L}$. $(\mathrm{F}=40 \%$; $\mathrm{D}=244)$. In this site, a few edible species were represented. A quite popular edible plant, P. indica $(\mathrm{F}=80 \% ; \mathrm{D}=299)$, was in abundance when compared to other edible plants while other important edible plants such as D. filix-mas $(\mathrm{F}=10 \% ; \mathrm{D}=18)$, Phyllanthus niruri $\mathrm{L}$. $(\mathrm{F}=10 \% ; \mathrm{D}=14)$, and Solanum nigrum $\mathrm{L} .(\mathrm{F}=10 \% ; \mathrm{D}=16)$ were quite rare.

Table 3. Species Importance Index Values for the partial canopy plot in Naga forest (Rf: relative frequency, RD: relative density, CP: Cover Percent, and IVI: Species Importance Value).

\begin{tabular}{|c|c|c|c|c|c|c|}
\hline Species & Classification & R.F & R.D & C.P & R.C & I.V \\
\hline Chrysopogon gryllus (L.) Trin. & Animal Forage & 0.2 & 0.09 & 0.82 & 0.41 & 0.83 \\
\hline Potentilla indica (Andrews) T.Wolf & Fruit & 0.1 & 0.19 & 0.31 & 0.15 & 0.73 \\
\hline Polygonum amplexicaule D. Don & Medicinal & 0.06 & 0.03 & 0.16 & 0.08 & 0.19 \\
\hline Mentha spicata L. & Medicinal & 0.1 & 0.0 & 0.09 & 0.04 & 0.19 \\
\hline Trifolium repens L. & Animal forage & 0.04 & 0.16 & 0.1 & 0.05 & 0.18 \\
\hline Dryopteris filix-mas (L.) Schott. & Vegetable & 0.02 & 0.01 & 0.14 & 0.07 & 0.106 \\
\hline Skimmia laureola Siebold \& Zucc. Ex Walp. & Medicinal & 0.02 & 0.01 & 0.09 & 0.05 & 0.07 \\
\hline Plantago major L. & Medicinal & 0.02 & 0.01 & 0.03 & 0.01 & 0.09 \\
\hline Rumex nepalensis Spreng. & Medicinal & 0.04 & 0.03 & 0.044 & 0.02 & 0.07 \\
\hline Asparagus racemosus Willd. & Vegetable & 0.02 & 0.009 & 0.02 & 0.01 & 0.04 \\
\hline Miscanthus nepalensis Hack. & Animal Forage & 0.02 & 0.09 & 0.03 & 0.015 & 0.04 \\
\hline Adiantum stenochlamys Baker & Medicinal & 0.02 & 0.01 & 0.02 & 0.01 & 0.04 \\
\hline Arisaema triphyllum (L.) Schott & Medicinal & 0.02 & 0.005 & 0.03 & 0.015 & 0.03 \\
\hline Dryopteris austriaca Schinz \& Thell. & Vegetable & 0.02 & 0.0079 & 0.03 & 0.015 & 0.03 \\
\hline Paeonaia emodi Wall. & Medicinal & 0.02 & 0.02 & 0.004 & 0.002 & 0.03 \\
\hline Geranium wallichianum D.Don ex Sweet & Medicinal & 0.02 & 0.08 & 0.01 & 0.005 & 0.02 \\
\hline Berberis lyceum Royle & Medicinal & 0.02 & 0.006 & 0.01 & 0.005 & 0.02 \\
\hline
\end{tabular}




\subsection{Rank Abundance Curve and Rarefaction Analyses}

In order to depict relative species abundance, species richness, and evenness, rank abundance curve was plotted. The $\mathrm{X}$ axis showed the abundance rank and the $\mathrm{Y}$ showed the relative abundance measured on a log scale. Figure 2 shows plant species data from closed canopy sites, open spaces, and partial covered tree sites. In this chart, the partial canopy site is dominated with very few species making up the bulk of the biomass while there is an extensive tail of relatively less abundant species. The curve of the open spaced site as shown in Figure 2 does not depict a steep slope, while the curve of the partial canopy site has a steep slope that indicates good evenness of species as compared to poor evenness in open spaces and closed canopy sites. The relative abundance of species in the closed canopy were quite low but the site displayed ample diversity in terms of the species variety. For the closed canopy site, the curve displayed a higher dominance value of a few species, but at the middle the curves fall sharply, then get stabled for an instance, and at the end fall again, depicting lower values of species abundance and rare species (Figure 2). Overall, the results demonstrate that the region has lower values of plant species cover and biomass that were mostly of functional equivalents of the dominant species but could differ with environmental requirement and tolerances.

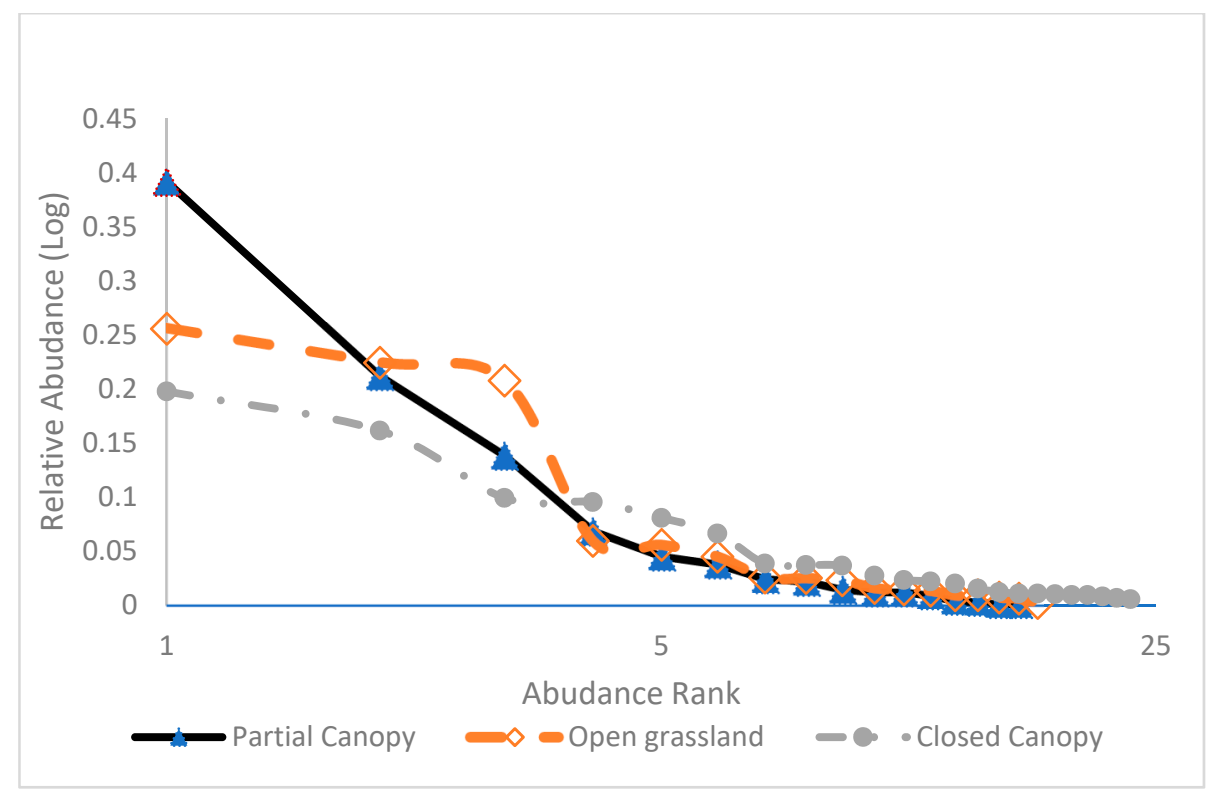

Figure 2. Rank Abundance Curve.

Rarefaction curves are used in evaluating sampling efforts. It describes how many samples are required for the analysis of diversity in a population. The rarefaction curves depict the number of species in the $X$ axis while the number of individuals found were placed in the $Y$ axis (Figure 3). The curve of the closed canopy site reaches the asymptote after steeply going upwards which shows that there was a good effort in sampling (Figure 3). Conversely, the partially covered tree site curve shows that the area was full of other unique species which still could be found if more sampling would have been conducted. 


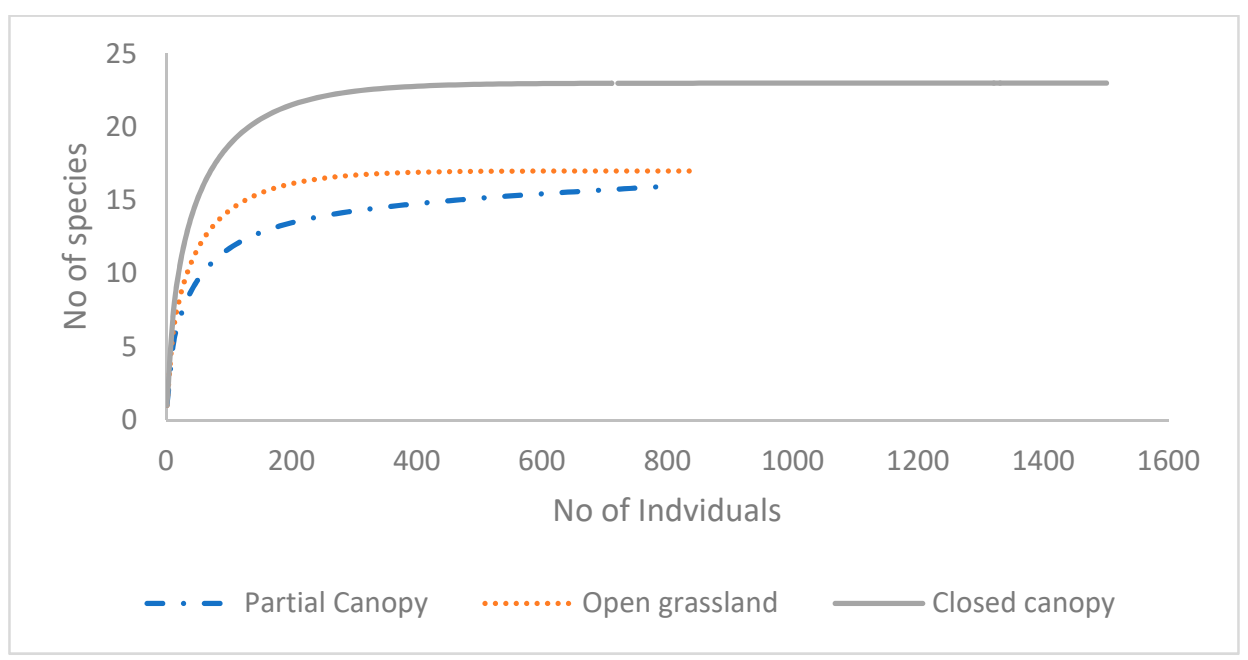

Figure 3. Individual Rarefaction Curve.

\subsection{Biodiversity Analyses}

The diversity of the closed canopy sites, open spaces, and partial covered tree sites were determined using various biodiversity indices (Table 4). It was observed that the Shannon diversity index was at the maximum in the partial covered tree sites. This higher value characterizes the fact that this community is more diverse, incorporating high richness and evenness, while the site that had the lowest value of Shannon index was the area with closed canopy. Comparatively, this site was low in diversity and species richness among the other sites. In order to determine dominance and species abundance, Simpson's index was calculated from all the sites. The results showed that the partially covered tree sites were more dominant even in terms of understory vegetation. Similarly, the Simpson's index was at its minimum in the closed canopy sites. The Margalef index for species richness, and Buzas and Gibson's for species evenness, also had a similar result as compared to the other indices being used. The major outcome shows that the various indices and plots represent higher biodiversity in the partial canopy sites. The Sørensen index showed low compositional similarity among the closed canopy, open spaced, and partial canopy sites. The Sørensen Similarity coefficient index displayed similarity less than $50 \%$ (Table 5). The maximum similarity observed was of $35 \%$ in between site 1 and 3 . Therefore it is inferred that there are less shared species among sites. This index tells that the endemic species in each of the site are rare.

Table 4. The average amount of indices and their comparisons in different sites.

\begin{tabular}{cccc}
\hline Indices & Sites \\
\hline & Site 1(C.C) & Site 2(O.S) & Site 3(P.C) \\
\hline Shannon H & 1.87 & 2.19 & 2.60 \\
Simpson_1-D & 0.77 & 0.84 & 0.89 \\
Margalef (Spp Richness) & 2.23 & 2.36 & 3.00 \\
Buzas and Gibson's evenness & 0.40 & 0.43 & 0.52 \\
\hline
\end{tabular}

Table 5. Sørensen coefficients showing similarity between different sites.

\begin{tabular}{ccc}
\hline $\mathrm{S}_{\mathrm{s}}$ Site 1\&2 & $\mathrm{S}_{\mathrm{s}}$ Site 1\&3 & $\mathrm{S}_{\mathrm{s}}$ Site 2\&3 \\
\hline $0.242(24 \%)$ & $0.35(35 \%)$ & $0.3(30 \%)$ \\
\hline
\end{tabular}

\section{Discussion}

Our study shows that the Naga Forest Reserve has an understory vegetation that is enriched with various NWFPs. These NWFPs are a key nexus with the forest community 
and their livelihood, and they contribute to an appropriate ecosystem functioning in the forest [56]. Among the NWFPs that were found in the region, the most dominant were the medicinal plants. This is in agreement with the study conducted by Qasim et al. [57] in which he inferred that $100 \%$ of the respondents from his study in the Himalayas were possessing and using medicinal plants in abundance. High species density in this region is explained by the moist temperate climate of the area, which is a characteristic of the Himalayas in this part of the world, and creates certain biodiversity hotspots as well [58]. The study demonstrated a visible difference in the understory species composition among closed canopy, open spaces, and partial canopy sites. Our study further advances the fact that the structure and composition of the understory vegetation varies with canopy cover, as reported in other studies $[25,59]$.

Findings of various studies showed the distribution of the understory vegetation is strongly affected by aspect, canopy cover, and elevation [60-62]. The maximum biodiversity, as shown by the Shannon, Simpson, and Margalef indices was found in the partial canopy site. It is explained by the fact that mostly the moderate canopy forests have high plant species, as they tend to support species from both closed as well as open canopy [63]. The partial canopy site was shown to have maximum abundance and species richness of both medicinal plants and grass species. It is because the moderate canopy forests have more availability of light, nutrients, and moisture [64]. As explained by Whitmore [65], canopy openings in the forest are likely to influence the establishment of species and help them grow in the environmental mosaic in a forest. A similar trend was observed by Sagar et al. [66], where the sites which exhibit intermediate levels of light intensity had the greatest herbaceous diversity.

The closed forest canopies in the present research exhibited a lower biodiversity as compared to the other sites. In evergreen forests, closed sites are usually less biodiverse, as showed by Mestre et al [67] in his experiment when they compared biodiversity in a deciduous forest and in evergreen dense forest. They inferred that the evergreen forest was least diverse. The authors concluded that upper story vegetation has a major effect on the richness and diversity of understory vegetation of mixed and pure forests. Open spaces showed a moderate amount of biodiversity when compared to other sites in the study. It could be because most herbs and shrubs do not grow in the high daylight environments that are created due to the canopy gaps [60]. Our study showed that the highest number of medicinal plants were available in the partial canopy sites, and the lowest in open spaces. It was in accordance with similar research conducted in Ayubia National Park KPK by Adnan and Hölscher [20], where it was concluded that the abundance of medicinal plants rises with the increased canopy cover while the density of grasses decreases with the increasing canopy cover. The low medicinal plant presence in open spaces can be explained due to the disturbed canopy cover. The disturbed cover story often leads to decline in medicinal plant diversity in the Himalayas [25].

All of the sites explored in this study displayed rich understory vegetation. The region exhibited many important medicinal plants that were endemic to this particular mountain system. There were quite a few medicinal plants such as $V$. wallichii, P. frutescens Britton, and G. wallichianum that had high F, and M. spicata that showed high F and D. However, other extremely valuable medicinal plants such as $P$. hexandrum, $H$. perforatum, $P$. ovata P. amplexicule, P. emodi, and B. lycium were quite rare, having smaller frequencies and density. This is due to the increasing market awareness of the important medicinal plants and, consequently, the illegal and unsustainable collection and trading of these medicinal plants, thus resulting in a decreased population of this valuable asset $[68,69]$ There were quite a few edible NWFPs that were available in the study area. These plants were found to be of moderate abundance, having normal frequencies and densities. Similar results were observed previously, corroborating the fact that people were using wild foods only for their daily household use, thus avoiding the decline of population and diversity [70,71]

The most abundant edible NWFP in the study site was P. indica. It is a common fruiting plant producing berries that are significantly used by the forest communities as a wild 
fruit. As this plant is available year-round, people heavily use it as a subsistence crop [72]. Just like the high diversity dominance and evenness observed in the partial canopy site, the rank abundance curve showed the abundance of this area to be highest as compared to other sites. These results were in accordance with Walker et al. [73], who showed low species abundance in the disturbed sites such as open spaces in the forest. In another study, it was concluded that the canopy gaps in the forest were responsible for a somewhat low abundance of understory vegetation. The undisturbed closed and partially closed forest canopies showed high species abundance [74]. The results were attained by obtaining the appropriate amount of samples as justified by the rarefaction curves. These curves were used in the data so that we could refrain from the pitfalls and hindrances that are often experienced while quantifying and comparing taxon richness [55].

\section{Conclusions and Policy Implications}

This study determined that the Naga Reserve Forest has a rich biodiversity of various highly important NWFPs. The most important and pivotal of them are the edible and medicinal plants. Furthermore, in our study, the closed canopy forest showed the lowest biodiversity, while the site with partial canopy showed the highest biodiversity of medicinal plants. It was seen that the areas such as open grasslands where grazing and human activities were routine had the least diversity of medicinal and edible plants.

Pakistan has a forest cover of more than $4.8 \%$ that is continuously undergoing deforestation at a rapid rate. The region has great diversity of vegetation, hosting about 6000 vascular plants in which about 400 species are endemic to Pakistan and about $80 \%$ of them are present in the northern and western mountains of the country. The current study has depicted that the few dense forests in the Pakistani Himalayas sustain a highly diverse medicinal flora. This high abundance of important and endemic plant species in the current study site have depicted an opportunity for providing diversification of products for not only the forest proximate communities but also enhancing the economy of the country.

Medicinal plants play an important role as a refuge for those jobless people who are vulnerable to extreme poverty. But the people involved in medicinal plant collection and trading are not earning what they deserve. It is due to managerial and organizational issues that the middleman in the business takes the lion's share, leaving these people in this vicious cycle of poverty. Our study recommends that the government take initiatives such as training people in the appropriate collection techniques for sustainable growth and production of medicinal flora. In order to increase more profitable employment opportunities in this business, the government must run programs under the umbrella of public and private partnerships incorporating production and processing technologies in the current scenario for accessing international trade markets. The current study has found out such biodiversity of medicinal plants in only one forest reserve. Further research in other forests and various ecosystems of the country will not only be able to provide diversification of floral products but also will add considerable value to the GDP of Pakistan.

Author Contributions: Conceptualization, Formal analysis, Writing-Original Draft Preparation, Funding Acquisition: M.Z. and A.J.; Resources and data curation: S.B.H. and D.M.Z.; WritingReview and Editing: A.U.H. and A.H. (Ahmad Hussain); Writing-Review and Editing, Visualization, Funding Acquisition: A.H. (Abeer Hashem), A.A.A. and E.F.A. All authors have read and agreed to the published version of the manuscript.

Funding: "This research was funded by HEC, grant number 3490" and "The APC was funded by Deanship of Scientific Research at King Saud University for funding this research group NO (RGP-271)".

Acknowledgments: Thanks are due to the Higher Education Commission (HEC) for the funding of this research under the project\# NRPU 3490. The authors would like to extend their sincere appreciation to the Deanship of Scientific Research at King Saud University for funding this research group NO (RGP-271).

Conflicts of Interest: The authors declare no conflict of interest. 


\section{References}

1. Mittermeier, R.A.; Gill, P.R.; Hoffman, M.; Pilgrim, J.; Brooks, T.; Mittermeier, C.G.; Lamoreux, J.; da Fonseca, G.A.B. Hotspots Revisited: Earth's Biologically Richest and Most Endangered Terrestrial Ecoregions; CEMEX: San Pedro Garza García, Mexico, 2005.

2. Khan, P.K.; Ansari, M.A.; Mohanty, S. Earthquake source characteristics along the arcuate Himalayan belt: Geodynamic implications. J. Earth Syst. Sci. 2014, 123, 1013-1030. [CrossRef]

3. Jan, G.; Khan, M.A.; Farhatullah, J.F.; Ahmad, M.; Jan, M.; Zafar, M. Ethnobotanical studies on some useful plants of Dir Kohistan valleys, KPK, Pakistan. Pak. J. Bot. 2011, 43, 1849-1852.

4. Sher, H.; Aldosari, A.; Ali, A.; de Boer, H.J. Economic benefits of high value medicinal plants to Pakistani communities: An analysis of current practice and potential. J. Ethnobiol. Ethnomed. 2014, 10, 71. [CrossRef] [PubMed]

5. Ahenkan, A.; Boon, E. Non-timber forest products (NTFPs): Clearing the confusion in semantics. J. Hum. Ecol. 2011, 33, 1-9. [CrossRef]

6. Shah, A.H.; Khan, S.M.; Shah, A.H.; Mehmood, A.; Rahman, I.U.; Ahmad, H. Cultural uses of plants among Basikhel tribe of district tor Ghar, Khyber Pakhtunkhwa, Pakistan. Pak. J. Bot. 2015, 47, $23-41$.

7. Ahmad, F.B.; Ismail, G. Medicinal plants used by Kadazandusun communities around Crocker Range. ASEAN Rev. Biodivers. Environ. Conserv. 2003, 1, 1-10.

8. Shah, S.; Khan, S.; Bussmann, R.W.; Ali, M.; Hussain, D.; Hussain, W. Quantitative ethnobotanical study of Indigenous knowledge on medicinal plants used by the tribal communities of Gokand Valley, District Buner, Khyber Pakhtunkhwa, Pakistan. Plants 2020, 9, 1001.

9. Fazal, H.I.N.A.; Ahmad, N.; Rashid, A.B.D.U.R.; Farooq, S. A checklist of phanerogamic flora of Haripur Hazara, Khyber Pakhtunkhwa, Pakistan. Pak. J. Bot. 2010, 42, 1511-1522.

10. Barkatullah, I.M.; Rauf, A.; Hadda, T.B.; Mubarak, M.S.; Patel, S. Quantitative ethnobotanical survey of medicinal flora thriving in Malakand Pass Hills, Khyber Pakhtunkhwa, Pakistan. J. Ethnopharmacol. 2015, 169, 335-346. [CrossRef] [PubMed]

11. Awan, A.A.; Akhtar, T.; Ahmed, M.J.; Murtaza, G. Quantitative ethnobotany of medicinal plants uses in the Jhelum valley, Azad Kashmir, Pakistan. Acta Ecol. Sin. 2020, 9, 1001. [CrossRef]

12. Government of Pakistan. 2007-2008. Economic Survey Govt. of Pakistan. Finance Division, Economic Advisory Wing; Government of Pakistan: Islamabad, Pakistan, 2008.

13. Haq, F.H.; Ahmad, H.; Alam, M.; Ahmad, I.; Ullah, R. Species diversity of vascular plants of Nandiar valley western Himalaya, Pakistan. Pak. J. Bot. 2010, 42, 213-229.

14. Zubair, M.; Jamil, A.; Zahid, D.M.; Hussain, S.B.; Aslam, K.; ul Haq, A. Vegetation resource inventory of Nwfps, in the state of Azad Jammu and Kashmir. Fresenius Environ. Bull. 2019, 28, 8591-8600.

15. Roy, A.; Kushwaha, S.P.S. Landscape level plant diversity characterization in Indian Himalayan region. In Plant Diversity in the Himalaya Hotspot Region; Berra, S., Das, A.P., Eds.; Bishen Singh Mahendra Pal Singh: Uttarakhand, India, 2018.

16. Ruiz-Jaén, M.C.; Aide, T.M. Vegetation structure, species diversity, and ecosystem processes as measures of restoration success. Forest Ecol. Manag. 2015, 218, 159-173. [CrossRef]

17. Grêt-Regamey, A.; Brunner, S.H.; Kienast, F. Mountain ecosystem services: Who cares? Mt. Res. Dev. 2012, 32. [CrossRef]

18. Rawal, R.S.; Rawal, R.; Rawat, B.; Negi, V.S.; Pathak, R. Plant species diversity and rarity patterns along altitude range covering treeline ecotone in Uttarakhand: Conservation implications. Trop. Ecol. 2018, 59, 225-239.

19. Tali, B.A.; Khuroo, A.A.; Nawchoo, I.A.; Ganie, A.H. Prioritizing conservation of medicinal flora in the Himalayan biodiversity hotspot: An integrated ecological and socioeconomic approach. Environ. Conserv. 2019, 46, 147-154. [CrossRef]

20. Adnan, M.; Hölscher, D. Diversity of medicinal plants among different forest-use types of the Pakistani Himalaya. Econ. Bot. 2012, 66, 344-356. [CrossRef] [PubMed]

21. Abbasi, A.M.; Khan, M.A.; Khan, N.; Shah, M.H. Ethnobotanical survey of medicinally important wild edible fruits species used by tribal communities of Lesser Himalayas-Pakistan. J. Ethnopharmacol. 2013, 148, 528-536. [CrossRef] [PubMed]

22. Rajbhandari, K.R.; Rai, S.K.; Bhatt, G.D. Endemic flowering plants of Nepal: An update. Bull. Dept. Plant Resour. 2016, 38, 106-144.

23. Sharma, J.; Upgupta, S.; Jayaraman, M.; Chaturvedi, R.K.; Bala, G.; Ravindranath, N.H. Vulnerability of forests in India: A national scale assessment. Environ. Manag. 2017, 60, 544-553. [CrossRef] [PubMed]

24. Quershi, M.A.; Ahmad, H.; Shah, A.U.; Khan, S.A. An earthquake risk assessment study of khyber pakhtunkhwa province pakistan. In Proceedings of the First International Conference on Emerging Trends in Engineering, Management and Sciences, Peshawar, Pakistan, 28-30 December 2014; pp. 1-11.

25. Mishra, B.P.; Tripathi, R.S.; Pandey, H.N. Effects of anthropogenic disturbance on plant diversity and community structure of a sacred grove in Meghalaya, north-east India. Biodivers. Conserv. 2004, 13, 421-436. [CrossRef]

26. Gilliam, F.S. The ecological significance of the herbaceous layer in temperate forest ecosystems. Bioscience 2007, 57, 845-858. [CrossRef]

27. D'amato, D.A.; Foster, D.R. Understory vegetation in old-growth and second-growth Tsuga canadensis forests in western Massachusetts. Forest Ecol. Manag. 2009, 257, 1043-1052. [CrossRef]

28. Bagaram, M.D.; Giuliarelli, G.; Chirici, F.; Giannetti, F.; Barbati, A. UAV Remote sensing for biodiversity monitoring: Are forest canopy gaps good covariates? Remote Sens. 2018, 10, 1397.

29. Nadkami, N.M.; Mewin, M.C.; Niedert, J. Forest canopies: Plant diversity. Encycl. Biodivers. 2001, 3, $27-40$. 
30. Keller, H.W. Tree canopy biodiversity: Student research experiences in Great Smoky Mountains National Park. Syst. Geogr. Plants 2004, 74, 47-65.

31. Ozanne, C.M.; Anhuf, D.; Boulter, S.L.; Keller, M.; Kitching, R.L.; Körner, C.; Stork, N.E. Biodiversity meets the atmosphere: A global view of forest canopies. Science 2003, 301, 183-186. [CrossRef] [PubMed]

32. Wright, J.S. Plant diversity in tropical forests: A review of mechanisms of species coexistence. Oecologia 2002, 130, 1-14. [CrossRef]

33. Nakamura, A.; Kitching, R.L.; Cao, M.; Creedy, T.J.; Fayle, T.M.; Freiberg, M.; Malhi, Y. Forests and their canopies: Achievements and horizons in canopy science. Trends Ecol. Evol. 2007, 32, 438-451. [CrossRef] [PubMed]

34. Barlow, J.; Lennox, G.D.; Ferreira, J.; Berenguer, E.; Lees, A.C.; Mac Nally, R.; Parry, L. Anthropogenic disturbance in tropical forests can double biodiversity loss from deforestation. Nature 2016, 535, 144. [CrossRef]

35. Whitworth, A.; Villacampa, J.; Brown, A.; Huarcaya, R.P.; Downie, R.; MacLeod, R. Past human disturbance effects upon biodiversity are greatest in the canopy; a case study on rainforest butterflies. PLoS ONE 2016, 11, e0150520. [CrossRef] [PubMed]

36. Kumar, V. Ethno-medicinal plants in five forest ranges in Dang district, south Gujarat, India. Indian J. Trop. Biodiv. 2015, 23, 1-9.

37. Shaheen, S.Y.; Bibi, M.; Hussain, H.; Iqbal Saira, I.; Safdar Laraib, S. A review on Geranium wallichianum D-Don ex-sweet: An endangered medicinal herb from Himalaya Region. Med. Aromat. Plants 2017, 6, 2167-2412. [CrossRef]

38. Salk, C.; Chazdon, R.; Waiswa, D. Thinking outside the plot: Monitoring forest biodiversity for social-ecological research. Ecol. Soc. 2020, 25, 1-11. [CrossRef]

39. Ishii, H.T.; Tanabe, S.I.; Hiura, T. Exploring the relationships among canopy structure, stand productivity, and biodiversity of temperate forest ecosystems. For. Sci. 2004, 50, 342-355.

40. Hart, S.A.; Chen, H.Y. Understory vegetation dynamics of North American boreal forests. Crit. Rev. Plant 2006, 25, 381-397. [CrossRef]

41. Peruzzi, L. Using scientific names guarantees universality of communication in science ... but are plant biologists aware of it? Plant Biosyst. Int. J. Deal. Asp. Plant Biol. 2020, 154, 1000-1002. [CrossRef]

42. Global Biodiversity Information Facility. Global Biodiversity Information System. 1999. Available online: http:/ /www.gbif.org/ species / 6 (accessed on 31 December 2020).

43. Angiosperm Phylogeny Group. An update of the angiosperm phylogeny group classification for the orders and families of flowering plants: APG III. Bot. J. Linn. Soc. 2009, 161, 105-121. [CrossRef]

44. Curtis, J.T.; Mcintosh, R.P. The interrelations of certain analytic and synthetic phytosociological characters. Ecology 1950, 31, 434-455. [CrossRef]

45. Miller, R.I.; Wiegert, R.G. Documenting completeness, species-area relations, and the species-abundance distribution of a regional flora. Ecology 1989, 70, 16-22. [CrossRef]

46. Wang, Y.; Shangguan, T. Discussion on calculating method of important values. J. Shanxi Univ. 2010, 33, 312-316.

47. Margalef, R. Information theory in biology. General Systems. Sci. Res. 1958, 3, 36-71.

48. Simpson, E. H Measurement of diversity. Nature 1949, 163, 688. [CrossRef]

49. Buzas, M.A.; Gibson, T.G. Species diversity: Benthonic foraminifera in western North Atlantic. Science 1969, 163, 72-75. [CrossRef]

50. Shannon, C.E.; Weaver, W. The Mathematical Theory of Communication; University of Illinois Press: Illinois, IL, USA, 1949.

51. Sørensen, T.A. A method of establishing groups of equal amplitude in plant sociology based on similarity of species content and its application to analyses of the vegetation on danish commons. Biol. Skar. 1948, 5, 1-34.

52. MacArthur, R. On the relative abundance of species. Am. Nat. 1960, 94, 25-36. [CrossRef]

53. Baker, J.D.; Harting, A.L.; Johanos, T.C. Use of discovery curves to assess abundance of Hawaiian monk seals. Mar. Mammal Sci. 2006, 22, 847-861. [CrossRef]

54. Hurlbert, S.H. The non-concept of species diversity, a critique and alternative parameters. Ecology 1971, 52, 577-586. [CrossRef] [PubMed]

55. Gotelli, N.J.; Colwell, R.K. Quantifying biodiversity: Procedures and pitfalls in the measurement and comparison of species richness. Ecol. Lett. 2001, 4, 379-391. [CrossRef]

56. Shackleton, S.; Gumbo, D. Contribution of non-wood forest products to livelihoods and poverty alleviation. In The Dry Forests and Woodlands of Africa; Chidumayo, E.N., Gumbo, D.J., Eds.; Routledge: Oxfordshire, UK, 2012; pp. 73-101.

57. Qasim, M.; Khan, M.Z.; Naz, A.; Khalid, S. An insight of ecosystem capitals and services of the Kaghan Valley: The Himalayan Region of Pakistan. Nat. Resour. 2013, 4, 163. [CrossRef]

58. Baig, M.B.; Straquadine, G.S. Sustainable agriculture ensures sustainable rural development: A reality or a myth. In Global Food Insecurity; Yaya, S.D., Draggan, S., Behnassi, M., Eds.; Springer: Dordrecht, The Netherlands, 2011; pp. 21-32.

59. Mölder, A.; Bernhardt-Römermann, M.; Schmidt, W. Herb-layer diversity in deciduous forests: Raised by tree richness or beaten by beech? For. Ecol. Manag. 2008, 256, 272-281. [CrossRef]

60. Thomsen, R.P.; Svenning, J.C.; Balslev, H. Overstory control of understory species composition in a near-natural temperate broadleaved forest in Denmark. Plant Ecol. 2005, 181, 113-126. [CrossRef]

61. Gracia Montané, F.; Piqué, J.; Retana, J. Overstory structure and topographic gradients determining diversity and abundance of understory shrub species in temperate forests in central Pyrenees (NE Spain). For. Ecol. Manag. 2007, 242, 391-397. [CrossRef]

62. Wulf, M.; Naaf, T. Herb layer response to broadleaf tree species with different leaf litter quality and canopy structure in temperate forests. J. Veg. Sci. 2009, 20, 517-526. [CrossRef] 
63. Arya, N.; Ram, J. Influence of canopy cover on vegetation in P. roxburghii sarg (chir-pine) dominated forests in Uttarakhand Himalaya, India. Int. J. Bioassays 2016, 5, 4617-4620. [CrossRef]

64. Gurarni, D.; Arya, N.; Yadava, A.; Ram, J. Studies on plant 2010biodiversity of pure Pinus roxburghii Sarg. forest and mixed pine-oak forest in Uttarakhand Himalaya. N. Y. Sci. J. 2010, 3, 1-5.

65. Whitmore, T.C. Gaps in the forest canopy. In Tropical Trees as Living Systems; Tomlinson, P.B., Zimmermann, T.H., Eds.; Cambridge University Press: Cambridge, UK, 1978.

66. Sagar, R.; Singh, A.; Singh, J.S. Differential effect of woody plant canopies on species composition and diversity of ground vegetation: A case study. Trop. Ecol. 2008, 49, 189.

67. Mestre, L.; Toro-Manríquez, M.; Soler, R.; Huertas-Herrera, A.; Martínez-Pastur, G.; Lencinas, M.V. The influence of canopy-layer composition on understory plant diversity in southern temperate forests. For. Ecosyst. 2017, 4, 6.

68. Larsen, H.O.; Olsen, C.S. Unsustainable collection and unfair trade? uncovering and assessing assumptions regarding Central Himalayan medicinal plant conservation. Biodivers. Conserv. 2007, 16, 1679.

69. Chen, S.-L.; Yu, H.; Luo, H.-M.; Wu, Q.; Li, C.-F.; Steinmetz, A. Conservation and sustainable use of medicinal plants: Problems, progress, and prospects. Chin. Med. 2016, 11, 1-10. [CrossRef] [PubMed]

70. Vandebroek, I.; Van Damme, P.; Van Puyvelde, L.; Arrazola, S.; De Kimpe, N. A comparison of traditional healers' medicinal plant knowledge in the Bolivian Andes and Amazon. Soc. Sci. Med. 2004, 59, 837-849. [CrossRef]

71. Uniyal, S.K.; Singh, K.N.; Jamwal, P.; Lal, B. Traditional use of medicinal plants among the tribal communities of Chhota Bhangal, Western Himalaya. J. Ethnobiol. Ethnomed. 2006, 2, 14-18. [CrossRef] [PubMed]

72. Ang, H.Y.; Subramani, T.; Yeap, S.K.; Omar, A.R.; Ho, W.Y.; Abdullah, M.P.; Alitheen, N.B. Immunomodulatory effects of Potentilla indica and Dendrophthoe pentandra on mice splenocytes and thymocytes. Exp. Ther. Med. 2014, 7, 1733-1737. [CrossRef] [PubMed]

73. Walker, B.H.; Kinzig, A.; Langridge, J. Plant attribute diversity, resilience, and ecosystem function: The nature and significance of dominant and minor species. Ecosystems 1999, 2, 95-113. [CrossRef]

74. Promis, A.; Gärtner, S.; Reif, A.; Cruz, G. Effects of canopy gaps on forest floor vascular and non-vascular plant species composition and diversity in an uneven-aged Nothofagus betuloides forest in Tierra del Fuego, Chile. Community Ecol. 2012, 13, 145-154. [CrossRef] 